\title{
Determinants of health outcome in individuals with asthma
}

\author{
Malin Axelsson*, Linda Ekerljung, Bo Lundbäck, Jan Lötvall \\ From EAACI International Severe Asthma Forum (ISAF 2012) \\ Gothenburg, Sweden. 11-13 October 2012
}

\section{Background}

For many individuals, asthma has great impact on their everyday life, not least in terms of medication treatment and disease management. Therefore, it is important to evaluate recommended treatments on an individual level. In that respect, estimations of health-related quality of life (HRQL) function as an essential health outcome, as they capture personal perspectives and experiences of everyday life with a chronic disease such as asthma. The aim was to identify determinants of health-related quality of life in adult individuals with asthma.

\section{Method}

Participants with asthma $(\mathrm{n}=487)$ derived from a population-based study completed questionnaires on asthma control, emotional status, adherence and HRQL. Additionally, data on the Five-factor model personality traits: neuroticism, extraversion, openness, agreeableness, conscientiousness were gathered. Data were statistically analyzed using $\mathrm{t}$-tests, bivariate correlations and multiple regressions.

\section{Results}

Participants, who perceived their asthma as being poorly controlled ( $\mathrm{n}=126,26.3 \%)$, reported both poorer emotional status and HRQL. Participants with poor physical HRQL seemed to have both poorer emotional status and asthma control. Moreover, participants with low levels of Extraversion were more likely to perceive their physical HRQL as worse. Participants with poor mental HRQL reported poorer emotional status and adherence to asthma medication as well as poorer asthma control. Additionally, participants with high levels of neuroticism and low levels of extraversion, agreeableness and/or conscientiousness perceived their mental HRQL as worse. Asthma control was identified as predictor for physical

Gothenburg University, Sahlgrenska Academy, Institute of Medicine, Krefting Research Centre, Sweden
HRQL. Emotional status, adherence to asthma medication, asthma control, neuroticism and agreeableness were identified as predictors for mental HRQL.

\section{Conclusion}

The current findings argue that in addition to medical examinations, we also need to consider asthmatics emotional status, adherence behavior, asthma control but also personality characteristics in evaluations of their health outcome.

Published: 3 May 2013

doi:10.1186/2045-7022-3-S1-P19

Cite this article as: Axelsson et al: Determinants of health outcome in individuals with asthma. Clinical and Translational Allergy 2013 3(Suppl 1): P19.
Submit your next manuscript to BioMed Central and take full advantage of:

- Convenient online submission

- Thorough peer review

- No space constraints or color figure charges

- Immediate publication on acceptance

- Inclusion in PubMed, CAS, Scopus and Google Scholar

- Research which is freely available for redistribution

Submit your manuscript at www.biomedcentral.com/submit
() Biomed Central
C Biomed Central

() 2013 Axelsson et al; licensee BioMed Central Ltd. This is an Open Access article distributed under the terms of the Creative Commons Attribution License (http://creativecommons.org/licenses/by/2.0), which permits unrestricted use, distribution, and reproduction in any medium, provided the original work is properly cited. 